\title{
Bacteriological and Histological Investigation of the Postpartum Bovine Uterus in Two Estonian Dairy Herds
}

\author{
By K. Kask ${ }^{l}, H$. Kindahl ${ }^{2}$ and H. Gustafsson ${ }^{3}$
}

\begin{abstract}
${ }^{1}$ Department of Obstetrics and Gynaecology, Faculty of Veterinary Medıcıne, Estonian Agricultural University, Tartu, Estonia, ${ }^{2}$ Department of Obstetrics and Gynaecology, Faculty of Veterınary Medicine, Swedish University of Agricultural Sciences, Uppsala, and ${ }^{3}$ Swedish Association for Livestock Breeding and Production, Eskilstuna, Sweden.
\end{abstract}

\begin{abstract}
Kask K, Kindahl H, Gustafsson H: Bacteriological and histological investigation of the postpartum bovine uterus in two estonian dairy herds. Acta vet. scand. 1998, 39, 423-432. - Postpartum uterine infections, endometrial histology and resumption of ovarian activity in cows were studied in 2 Estonian dairy herds with different herd sizes, milk yields and management systems. Ten cows at Farm A and 5 cows at Farm B were studied in the experiment. All cows in the study had normal calving performance. Endometrial biopsies for bacteriological and histological examinations were collected once a week starting on the second week postpartum and contınuing for 7 weeks postpartum. Milk progesterone samples were collected twice a week during the whole study period. In both herds, the uterine flora contaned mainly facultative anaerobic bacteria (Streptococcus spp., E. coll, Staphylococcus spp., Proteus vulgaris). Among obligate anaerobic bacteria only Bacteroides spp. were found. After 7 weeks of collection at farm A, a bacterial uterine flora still persisted in 2 of the cows. At farm B, on the other hand, bacterial elımination was complete after 6 weeks. Presence of inflammatory cells in uterne histology specimens remained higher at the end of collection and resumption of ovarian activity was delayed at farm A. After 7 weeks postpartum, only 6 of the 10 cows at farm A had resumed ovarian cyclicity, while at farm B the first oestrous cycle had occurred in all cows. The study showed that differences regarding uterine infections and their clearance occured between farms and, despite these differences, cows with normal calving performance will effectively recover without any treatment.
\end{abstract}

cow; uterine bacteriology; uterine histology; ovarian activity.

\section{Introduction}

Cattle breeding in Estonia has always been based on milk production. Milk and milk products form an important part of human nutrition and are the main agricultural export products at the moment. Dairy cattle production makes up about $60 \%$ of the national agricultural commodity production. The total number of cows was 173200 in December 1996, and the average milk production was $3913 \mathrm{~kg}$. The poten- tial annual production in Estonia is, however, $6000-8000 \mathrm{~kg}$ milk per cow. These production levels have already been achieved in some herds, where feeding and management are outstanding.

According to official animal records (1996), the reasons for culling cows in Estonian herds are foremost fertility problems (33.9\%). Many of the fertility problems are linked to suboptimal 
management factors and feeding of the cows. Many farmers and veterinarians believe that the use of preventive antibiotic treatments can compensate for poor management. This is also the case where there is no obvious need for the treatment. There are some farms where all an1mals were treated in the postpartum period using antibiotics and hormonal drugs. In the future, such treatments should be avoided for animal health reasons and in order to decrease pharmacological residues in meat and milk.

The postpartum period (pp) is important in the life of the dairy cow. During this period the animal should eliminate intrauterine infections, that may be present, and re-establish normal uterine and ovarian functions. Diseases such as endometritis, mastitis and ketosis are common during pp and some of the problems are caused by micro-organisms. The intrauterine micro-organisms isolated durıng $\mathrm{pp}$ from the uterus have been described in many early studies and have been found to prolong the uterine involution and also very often lead to early culling of the cows (Roberts 1967, Bostedt 1984, Fredriksson et al. 1985, Kindahl et al. 1986, Bekana 1996). The risk for uterine infections increases in cows with abnormal calving or retained fetal membranes (RFM) (Ruder et al. 1981a, Olson et al. 1984, Fredriksson et al. 1985, Markusfeld 1993, Bekana et al. 1994a,b).

The present study was conducted on 2 Estonian dairy farms of different size and milk yield and with different management systems. The aims were to study the postpartum period of cows with normal calving. The main emphasis was placed on uterine infections, but also the re-establıshment of ovarian cyclicity was studied, using milk progesterone analyses. An important goal was also, based on the results of the study, to give information to Estonian veterinarians and farm owners about treatment regimes for postpartum cows.

\section{Materials and methods}

Farms

Two farms (A and B) both belonging to the State farm in Tartu County, were studied. Some data on the farms are given in Table 1. Feeding standards on both farms were according to the milk yield of the cows. The rations in farm A consisted of hay, straw, silage and fodder beet. In farm B the study was conducted in late summer and rations were based on pasture and other green feeds. On both farms, some concentrates were also given, the origin of which was not industrial and consisted mainly of mixtures of different grains made on the same state farm. On both farms the cows were given $400 \mathrm{~g}$ of concentrate per liter of daily milk yield.

\section{Animals}

Fifteen Estonian dairy cows were used in the experiment, 10 of which belonged to farm A and 5 to farm B. They were of Estonian black and white breed (EBW) and of Estonian red breed (ER). Animals on farm A calved on March 12, $1996(\mathrm{n}=5)$ and March 13, 1996 $(n=5)$. None had a difficult calving. One animal had retention of placenta for $24 \mathrm{~h}$ after calving. Anımals from farm B calved on September 1, $1996(\mathrm{n}=3)$ and September 3, $1996(n=2)$, none having difficult calvings or retained fetal membranes. No treatment was given to the animals either before or after calving. This group of animals was at pasture during daytime.

Collection of specimens for bacteriology and histology

Each animal in this study was sampled for bacteriological and histological examination once a week, startıng within 10 days after parturition and continuing for 7 weeks on farm A and for 6 weeks on farm B. Endometrial biopsies were aseptically collected according to the techniques and methods described by Fredriksson et al. (1985) and Bekana et al. (1994b). 
Table 1 Characteristics of 2 Estonian farms used in the study

\begin{tabular}{|c|c|c|c|c|c|}
\hline Farm & $\begin{array}{l}\text { No } \\
\text { cows }\end{array}$ & Breeds & $\begin{array}{l}\text { Milk } \\
\text { prod kg }\end{array}$ & Milkıng & Housing, management \\
\hline A & 601 & $\begin{array}{l}\text { ER } \\
\text { SLB } \\
\text { EBW }\end{array}$ & 4900 & $\begin{array}{l}2 \times \text { per day, } \\
\text { machine } \\
\text { pipeline }\end{array}$ & $\begin{array}{l}\text { Tyıng system. Removal of manure by tractor } \\
\text { scraper once a day. Feedıng also by tractor. } \\
\text { Routıne treatment of endometritıs using antıbıtıc }\end{array}$ \\
\hline B & 394 & $\begin{array}{l}\text { EBW } \\
\text { SRB }\end{array}$ & 5200 & $\begin{array}{l}2 \times \text { per day, } \\
\text { machine } \\
\text { pipeline }\end{array}$ & $\begin{array}{l}\text { Tyıng system. Removal of manure twice a day by } \\
\text { an electric scraper. Feeding manually from wagons. } \\
\text { Routine use of intrauterine antibiotic treatment in } \\
\text { most of the postpartum cows. }\end{array}$ \\
\hline
\end{tabular}

$\mathrm{ER}=$ Estonian red breed; EBW $=$ Estonian black and white breed, SLB $=$ Holsteın Friesian breed; SRB = Swedish red and white breed

The cow was restrained, the faeces removed from the rectum and the tail was secured, the perineal area and vulva were washed carefully and the vulvar area and the vestibulum were disinfected using a mild iodophore. Then the vulvar lips were parted to introduce an outer protective stainless steel tube. The instrument was fixed in the external opening of the cervix. A long guarded culture instrument was advanced into the uterus by cervical manipulation (Messier et al. 1984, Fredriksson et al 1985). The instrument was opened and a milled cavity on the tip of the instrument was located with the forefinger of the hand in the rectum. This cav1ty, with its sharpened edge, formed a curette by which biopsies were obtained from the endometrium.

Biopsies for bacteriological examination were immediately placed in thioglycolate medium for transportation to the laboratory for bacteriological examination. Samples were cultured within $2 \mathrm{~h}$. Isolation of the bacterial species was performed at the Department of Veterinary Microbiology, Estonian Agricultural University, Tartu using standard bacteriological procedures. Plates cultivated aerobically were examined after $24 \mathrm{~h}$ and $48 \mathrm{~h}$ and plates cultivated anaerobically after $48 \mathrm{~h}$ and $168 \mathrm{~h}$. All bacterial isolates were identıfied according to Bergey's
Manual of Systematic Bacteriology (Holt 1986). The results were intepreted as follows:

$$
\begin{aligned}
& 0=\text { no bacteria; } \\
& 1=\text { mild growth; } \\
& 2=\text { moderate growth; } \\
& 3=\text { heavy growth. }
\end{aligned}
$$

Biopsies for histological examination were placed in $10 \%$ formol salıne solution. After fixation, tissues were trimmed, embedded in paraffin, sectioned at $6 \mu \mathrm{m}$ and stained with haematoxylin and eosin. All the procedures were made in the Histology laboratory, Department of Obstetrics and Gynaecology, Swedish University of Agricultural Sciences in Uppsala. Investigations were made under the microscope for presence of inflammatory cells in the endometrium. Infiltration of the neutrophils in the biopsy specimen was considered as normal to slight, medium or dense. The diffuse cellular reaction involving also the mononuclear cells was assessed by countıng the inflammatory cells in 6 high power fields chosen randomly and calculating the average number of cells per high power field (Griffin et al. 1974). The results were interpreted as follows:

Normal to slight infiltration $=0$ to 29 cells per field;

Medium infiltration $=30$ to 80 cells per field; Dense infiltration $=$ more than 80 cells per field. 


\section{Progesterone}

Milk samples for progesterone determination were collected twice weekly, starting on the same day as the first biopsies were taken and continuing until the end of the study. Milk sampling was performed within $60 \mathrm{~min}$ after the morning milking. Samples from each cow were collected into plastic tubes containing $100 \mu \mathrm{l}$ of preservative (Bronopol 2\% + MTB 0.05\%) and stored at $4{ }^{\circ} \mathrm{C}$ until assay. Analyses were performed at the Department of Clinical Chemistry, Swedish University of Agricultural Sciences in Uppsala. The content of milk progesterone was determined by RIA (Spectria, Orion Diagnostica, Espoo, Finland). The interassay coefficient was below $14 \%$ and the intraassay coefficient was below $17 \%$. Detection limit of the assay was $1 \mathrm{nmol} / \mathrm{l}$. The minimum progesterone value for detection of luteal activity was considered to be $6.7 \mathrm{nmol} / 1$ (Laitinen 1983).

\section{Statistical analyses}

The statistical analyses were made using the Statistical Analysis System (SAS Institute Inc. 1994). The FREQ procedure for Chi-Square test and Mantel-Haenszel Chi-Square test were used. $\mathrm{p}<0.05$ was considered as a significant difference.

\section{Results}

The overall results from bacteriological and histological examinations are presented in Table 2.

\section{Bacteriology}

The results of bacteriological examination are presented in Tables 2 and 3. Altogether 94 biopsies were collected from the 15 animals. From these, 45 were found to be positive and the remaining 49 biopsies negative. Six samples are missing due to problems during collection. Five samples from the positive biopsies showed mixed infections and the remaining 40 samples were facultative anaerobic bacteria in pure culture. The mixed cultures contained mainly Bacteroides spp., Escherichia coli and Streptococcus spp. In one case also Proteus vulgaris was involved. A total of 58 isolates were identified among the 45 bacteriologically positive biopsies. From these, 5 were obligate anaerobic bacteria and 53 facultative anaerobic bacteria. The most common anaerobic pathogens were Streptococcus spp, E. coli and Staphylococcus spp. The only obligate anaerobic bacteria found were Bacteroides spp. (Table 3).

The highest incidence of bacteriological growth, and also the highest number of bacterial species, was found during the first 4 weeks after parturition. Elimination of the bacterial isolates is shown in Figs. 1 and 2 (Farm A versus B). After eight weeks postpartum, 1 out of 15 animals still remained bacteriologically positive (Table 2). No totally negative anımals were found during the collection time at either farms, but the largest number of bacteriologically positive samples was seen on farm A. No significant difference between farms was detected $(\mathrm{p}>0.05)$.

\section{Histology}

Altogether 92 biopsies were collected for histology. A total of 8 biopsies are missing due to difficulties in collection. The results of the histological examinations, according to the farms, are presented in Table 2, and Figs. 1 and 2. Arithmetic means of the real numbers of the inflammatory cells and the percentage of cows with cell infiltration are given simultaneously in the figures. No significant difference between the 2 farms was detected $(p>0.05)$.

\section{Progesterone}

On farm A, 6 out of 10 animals showed resumption of ovarian cycles during the first 8 
Table 2. Bactenological and histological results durıng the study period in indıvidual anımals on farm A and farm B.

\begin{tabular}{|c|c|c|c|c|c|c|c|c|c|c|c|c|c|c|}
\hline \multirow[b]{2}{*}{ Cow No } & \multicolumn{7}{|c|}{ Bacterıology during 2-8 weeks pp } & \multicolumn{7}{|c|}{ Histology durıng 2-8 weeks pp } \\
\hline & 2 & 3 & 4 & 5 & 6 & 7 & 8 & 2 & 3 & 4 & 5 & 6 & 7 & 8 \\
\hline \multicolumn{15}{|l|}{ Farm A: } \\
\hline 2486 & 3 & 2 & 0 & 0 & 0 & 0 & $?$ & $\mathrm{D}$ & $\mathrm{D}$ & $\mathbf{M}$ & $?$ & $\mathbf{M}$ & $\mathbf{M}$ & $\mathbf{M}$ \\
\hline 9933 & 3 & 2 & 2 & 0 & 0 & 0 & $?$ & $?$ & $\mathbf{M}$ & $\mathbf{M}$ & $\mathbf{M}$ & $\mathbf{S}$ & $\mathrm{S}$ & $\mathrm{S}$ \\
\hline 9479 & 3 & 3 & 3 & 3 & 2 & 2 & 1 & $\mathrm{D}$ & $\mathbf{M}$ & $?$ & $\mathbf{M}$ & $\mathbf{M}$ & $\mathbf{M}$ & $\mathrm{M}$ \\
\hline 2382 & 2 & 3 & 2 & 0 & 0 & 0 & $?$ & $\mathbf{M}$ & $?$ & D & $\mathrm{M}$ & $\mathrm{M}$ & $\mathbf{M}$ & $\mathrm{S}$ \\
\hline 2703 & 3 & 0 & 1 & 0 & 0 & 0 & $?$ & $\mathbf{M}$ & $\mathbf{M}$ & $\mathbf{M}$ & $\mathrm{S}$ & $\mathrm{S}$ & $\mathrm{S}$ & $\mathrm{S}$ \\
\hline 2972 & 3 & 3 & 3 & 3 & 0 & 0 & $?$ & $\mathbf{M}$ & $\mathrm{S}$ & $\mathrm{D}$ & $\mathbf{M}$ & $\mathbf{M}$ & $S$ & $?$ \\
\hline 2881 & 0 & 2 & 2 & 2 & 3 & 0 & 0 & $\mathrm{D}$ & $\mathbf{M}$ & $\mathrm{M}$ & $\mathrm{M}$ & $\mathbf{M}$ & $\mathbf{M}$ & M \\
\hline 9606 & 3 & 1 & 2 & 2 & 0 & 0 & 0 & $\mathbf{M}$ & $\mathbf{M}$ & $\mathrm{M}$ & $\mathrm{M}$ & $\mathrm{D}$ & $\mathbf{M}$ & D \\
\hline 2988 & 3 & 3 & 2 & 0 & 0 & 0 & 0 & $\mathbf{M}$ & $\mathbf{M}$ & $\mathbf{M}$ & $\mathrm{M}$ & $?$ & D & $S$ \\
\hline 2471 & 3 & 2 & 0 & 0 & 0 & 0 & $?$ & $\mathbf{M}$ & $\mathrm{S}$ & $\mathrm{M}$ & $S$ & $\mathrm{~S}$ & $?$ & $?$ \\
\hline \multicolumn{15}{|l|}{ Farm B: } \\
\hline 2348 & 0 & 3 & 2 & 1 & 0 & 0 & & $\mathrm{D}$ & $\mathbf{M}$ & $\mathbf{M}$ & $\mathrm{M}$ & $\mathbf{M}$ & $S$ & \\
\hline 4283 & 0 & 2 & 2 & 0 & 0 & 0 & & $\mathbf{M}$ & $\mathbf{M}$ & $\mathbf{M}$ & $S$ & $\mathrm{~S}$ & $S$ & \\
\hline 1449 & 3 & 0 & 0 & 0 & 0 & 0 & & $\mathrm{D}$ & $\mathbf{M}$ & $\mathbf{M}$ & $\mathrm{M}$ & $\mathbf{M}$ & $\mathrm{S}$ & \\
\hline 1311 & 3 & 3 & 2 & 1 & 0 & 0 & & $\mathbf{M}$ & $\mathbf{M}$ & $\mathbf{M}$ & $\mathbf{M}$ & $\mathbf{M}$ & $\mathrm{S}$ & \\
\hline 1464 & 2 & 0 & 0 & 0 & 0 & 0 & & $\mathbf{M}$ & $\mathbf{M}$ & $\mathbf{M}$ & $\mathrm{S}$ & $\mathbf{S}$ & $S$ & \\
\hline
\end{tabular}

$0=$ no bacteria; $1=$ mild growth; 2 = moderate growth; $3=$ heavy growth; $?=$ missing sample; $\mathrm{S}=$ normal to slight infiltration; $\mathbf{M}=$ medium infiltration; $\mathrm{D}=$ dense infiltration.

Table 3. Presence and elimination of bacteria (number of isolates) from the uterus in 15 cows on 2 different farms startıng on the second week postpartum and contınuing 7 and 6 weeks postpartum.

\begin{tabular}{lllllllll}
\hline & \multicolumn{8}{c}{ Week Postpartum } \\
\cline { 2 - 8 } Bacteria & 2 & 3 & 4 & 5 & 6 & 7 & 8 \\
\hline
\end{tabular}

Farm $A(n=10)$

Facultative anaerobic:

Streptococcus spp.

E. coll

Staphylococcus spp.

Proteus vulgaris

Pseudomonas aeruginosa

Others

Total $=43$

Obligate anaerobic:

Bacteroides spp.

Total $=5$

$\begin{array}{rr}3 & 2 \\ 1 & 3 \\ 2 & 3 \\ 4 & 0 \\ 1 & 1 \\ 2 & 2 \\ 13 & 1\end{array}$

$\begin{array}{rl}2 & 2 \\ 3 & 2 \\ 3 & 3 \\ 0 & 0 \\ 1 & 1 \\ 2 & 1 \\ 11 & 9\end{array}$

3
0
1
0
0
1
5

$\begin{array}{lll}1 & 1 & 0 \\ 1 & 0 & 0 \\ 0 & 0 & 1 \\ 0 & 0 & 0 \\ 1 & 0 & 0 \\ 0 & 0 & 0 \\ 3 & 1 & 1\end{array}$

Farm $B(n=5)$

Facultative anaerobic:

\begin{tabular}{|c|c|c|c|c|c|}
\hline Streptococcus spp & 2 & 1 & 1 & 1 & 0 \\
\hline$E$ coll & 0 & 2 & 2 & 0 & 0 \\
\hline Staphylococcus spp. & 1 & 0 & 0 & 0 & 0 \\
\hline Total $=10$ & 3 & 3 & 3 & 1 & 0 \\
\hline
\end{tabular}




\section{FARM A}

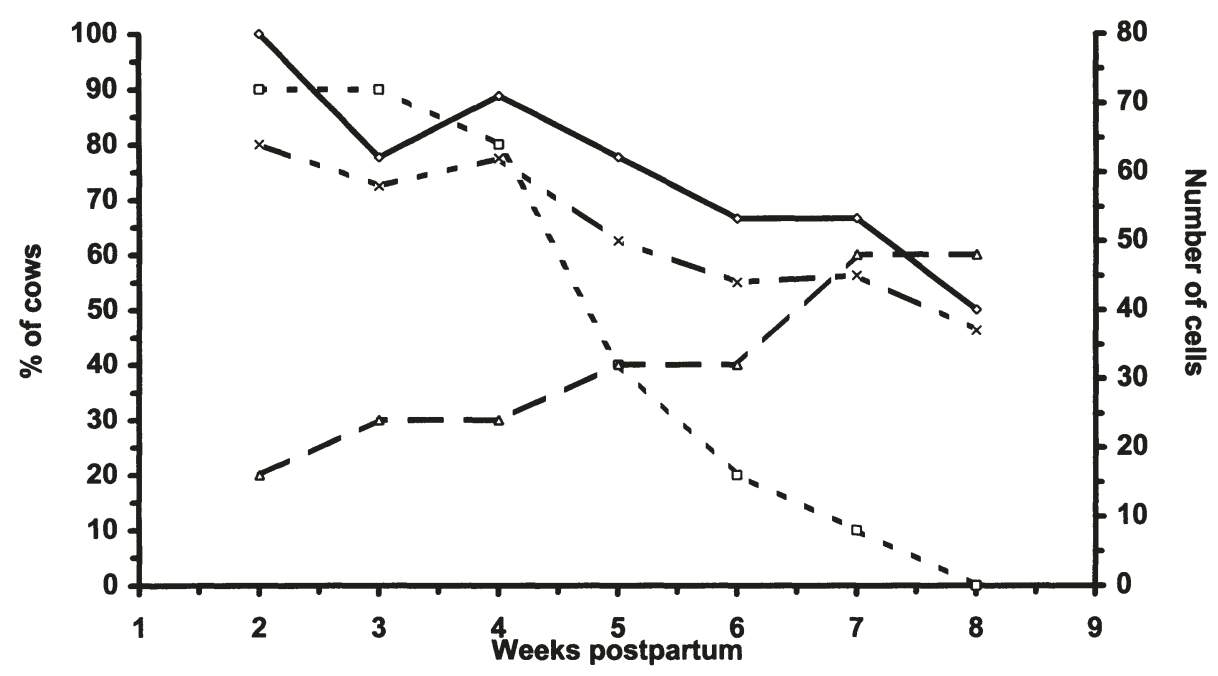

FARM B

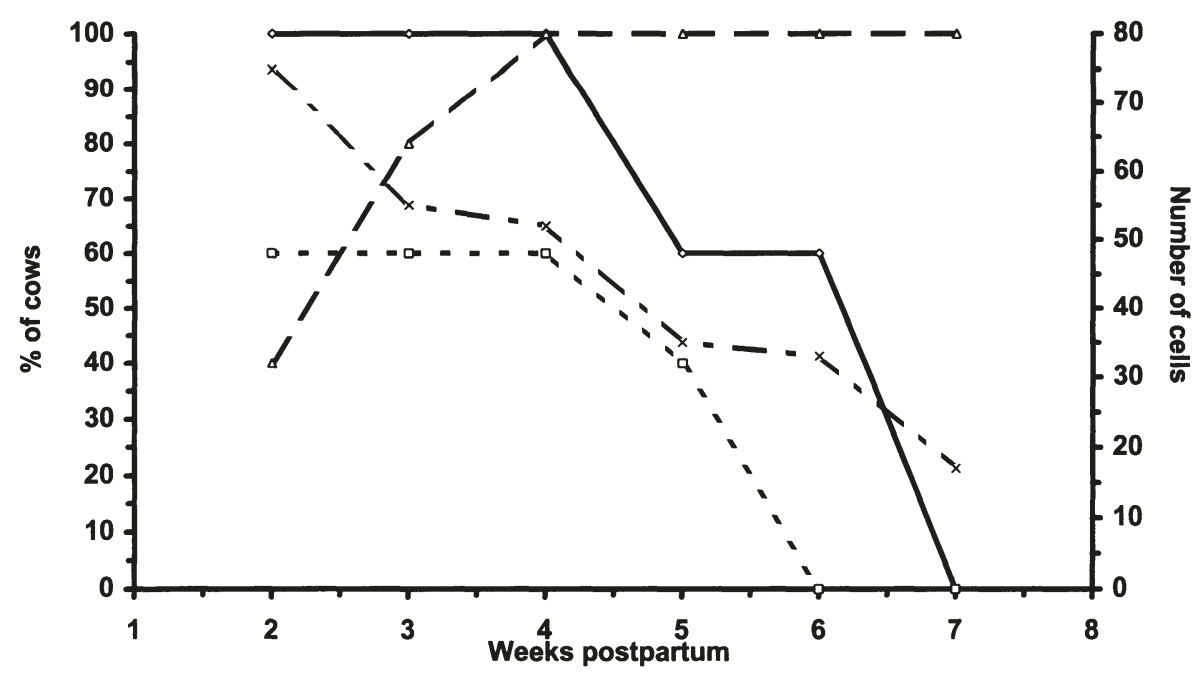

F1gure 1 (farm A) and Figure 2 (farm B). Results of uterine bacteriological (uterine infections) (- - - $\square$ ) studies and resumption of ovarian activity $(--\triangle)$ in 10 cows on farm $A$ and 5 cows on farm B startıng in the second week postpartum and contınuing 7 weeks postpartum (6 weeks on farm B) Arthmetric means of cell numbers (- - $\times)$, (right Y-axis), and percentage of cows with medium or dense cell infiltration in the endometruum $(-\diamond)$ are given simultaneously. 
weeks postpartum (values more than 6 . nmol-1-1 ${ }^{-1}$ ). In 4 animals progesterone levels were found to be low during the whole period. On farm B, all 5 anımals showed resumption of ovarian cyclicity during the 7 weeks period. Three of them started cyclicity in the third week postpartum. Results are presented in Figs. 1 and 2 .

\section{Discussion}

The early studies from the sixties and seventies indicate that bacteria have been recovered from up to $93 \%$ of all cows during the early postpartum period (Elliott et al. 1968, Griffin et al. 1974). Later studies (Messier et al. 1984, Fredriksson et al. 1985, Bekana et al. 1996) have shown that intrauterine infections are not commonly found in cows with normal calving. In the present study, the methodology of Fredriksson et al. (1985) and Bekana et al. (1994b) was used. The results of bacteriological examinations of endometrial tissue biopsies are similar in principal when comparing these later studies, but they differ between bacterial species found. In the present study, the uterine flora contained mainly facultative anaerobic bacteria, but in no case was found Actınomyces pyogenes. This bacteria is the most commonly isolated bacteria in almost all postpartum bacteriological studies and has been considered as one of the most pathogenic agents, together with Fusobacterium necrophorum and Bacteroides spp. (Hartigan et al. 1974, Hartigan 1978, Ruder et al. 1981b, Fredriksson et al. 1985, Bekana et al. 1994b, Kaneko et al. 1997). Also, in a similar experıment conducted in Sweden at the same time and using also healthy animals, A. pyogenes was found to be one of the dominating isolates during the first 3 weeks postpartum, together with Bacteroides spp and F. necrophorum (Kask et al. 1998).

Among obligate anaerobic bacteria in the pre- sent study, only Bacteroides spp. were found in 5 cases. In contrast to the Swedish study (Kask et al. 1998), the present study showed no totally negative animals. There was a tendency on farm $B$ for fewer bacteria to be found during the collection period compared with farm $\mathrm{A}$. The difference might be due to management factors such as unhygienic conditions before and after parturition when negative pressure is induced in the birth canal, and the birth canal is open for a period (Arthur et al. 1996). There were different hygiene conditions between the farms, with a better situation on farm $\mathrm{B}$, where manure was removed twice a day. On farm A, removal was done usually only once a day. Unhygienic conditions in and around the cow may increase the bacterial contamınation of the vestibulum and vagina, from where bacteria can easily migrate to the uterus after parturition. Especially $E$. coli, which was one of the dominating bacteria in this study, will mostly enter the uterus in such a way (Bretzlaff et al. 1982).

Generally, most of the non-specific bacteria found in this study, Streptococci, Staphylococci and $E$. coli, are short-lived, since the natural defence mechanism of the cow normally copes with invading bacteria. Thus the bacteria make sporadic and transient appearances in the uterine lumen without affecting subsequent fertility (Griffin et al. 1974, Hartigan 1978, Ruder et al. 1981a).

The highest incidence of isolates was detected during the first 5 weeks postpartum, after which the number decreased and at the end of the experiment ( 8 weeks postpartum) only one animal remained positive. This animal belonged to farm $\mathrm{A}$ and also had delayed delivery of placenta $(24 \mathrm{~h})$. This might have been a cause of delayed elimination of bacteria in that particular animal.

Histological results differed between farms and there were also differences between the time for bacterial elimination and normal histology. Af- 
ter 8 weeks postpartum on farm A, medium and dense inflammatory cell infiltration was still found. The situation was better on farm B, where all 5 animals only had normal to slight infiltration of inflammatory cells in the endometrium by week 7 postpartum. According to Skjerven (1956), slight infiltration cannot affect subsequent fertility. On farm A, samples were missing during the last week in 3 animals, but 6 out of 10 animals had different degrees of infiltration. One animal still had a dense infiltration but without bacteria after 5 weeks. Also many animals that were still bacteriologically positive had only slight infiltration in the endometrium.

According to the progesterone values, 6 out of 10 animals on farm A showed resumption of ovarian cycles during the first 8 weeks postpartum. On farm B, all animals had started cycling by week 7 postpartum. There is a link between uterine involution and resumption of ovarian activity (Lamming et al. 1982, Kindahl et al. 1984, Butler et al. 1989). Of the animals with low levels of progesterone during the whole experimental period, one animal had dense, one animal medium and 2 animals had normal to slight infiltration in the endometrium at the end of experiment. On the other hand, among those animals that started cyclicity there were also cases of medium infiltration, especially on farm B. The reason might be a negative energy balance of the animals on Farm A. It is well known that negative energy balance after calving can cause delayed resumption of ovarian activity (Karg et al. 1982, Hanzen 1986, Imakawa et al. 1987). There are also suggestions that reduced resistance, which is related to negative energy balance, may play a role in delayed return of normal uterine function (Elliott et al. 1968). However, nutritional studies were not included within the scope of this study.

\section{Conclusions}

There were different hygienic conditions on the 2 farms in the experiment, and this seems to influence the results of the present study. Cows from farm B showed a tendency for less bacteriological contents and less histological changes in the uterus, and earlier resumption of ovarian activity, as compared with animals on farm A. Another important conclusion is that, despite the different hygienic conditions, all cows were recovering without any treatment. This leads to the suggestion that cows with normal calving performance do not need any antibiotic treatment.

\section{Acknowledgements}

This work was financially supported by the Swedish Council for Forestry and Agricultural Research. The authors wish to express their sincere gratitude to Dr. Mihkel Vihur for assistance in collection of milk samples and to Dr. Ausleete Juhkam for assistance in bacteriological examınation

\section{References}

Arthur GH, Noakes DE, Pearson H, Parkinson TJ Veterinary Reproduction and Obstetrics W B Saunders Company Ltd 1996, pp. 389-396.

Bekana M Clinical, ultrasonographic, bactenological and hormonal studies in post-partum cows with particular emphasis on retained fetal membranes Uppsala, Sweden 1996. PhD Thesis.

Bekana M, Ekman T, Kindahl $H$ Ultrasonography of the postpartum uterus with retained fetal membranes. J. Vet. Med. A. 1994a, 41, 653-662.

Bekana M, Jonsson P, Ekman T, Kindahl H Intrauterine bacterial findings in postpartum cows with retained fetal membranes $\mathrm{J}$ Vet. Med A. 1994b, 41, 663-670

Bekana M, Jonsson P, Kindahl H Intrauterine bacterial findings and hormonal profiles in post-partum cows with normal puerperium. Acta vet. scand 1996, 37, 251-263.

Bostedt $H$ Uterine infections in the postpartum perod. 10th International Congress on Anımal Reproduction and AI, Urbana Champargn Illinots, June 10-14, 1984, Vol IV, III-25-III-33. 
Bretzlaff KN, Whitmore HL, Spahr SL, Ott RS. Inc1dence and treatments of postpartum reproductive problems in a dairy herd. Theriogenology 1982 , $17,527-535$.

Butler WR, Smith RD Interrelationships between energy balance and postpartum reproductive function in dairy cattle. J. Dairy Science 1989, 72, 767-783

Ellıott L, McMahon KJ, Gler HT, Marion GB. Uterus of the cow after parturition: bacterial content. Am. J vet. Res. 1968, 29, 77-81

Fredriksson G, Kindahl H, Sandstedt K, Edqvist L-E. Intrauterine bacterial findings and release of $\mathrm{PGF}_{2 \alpha}$ in the postpartum dairy cow. $\mathrm{Zbl}$ Vet. Med. A. 1985, 32, 368-380.

Griffin JFT, Hartigan PJ, Nunn WR: Non-specific uterıne infection and bovine fertility. 1. Infections patterns and endometrits during the first seven weeks postpartum. Theriogenology 1974, 1, 91106.

Hanzen $\mathrm{CH} \cdot$ Endocrine regulation of postpartum ovarian activity in cattle: a review. Reprod. Nutr. Dev. 1986, 26, 1219-1230.

Hartigan PJ The role of non-specific uterine infection in the infertility of clinically normal repeatbreeder cows. Vet. Science Comm. 1978, 1, 307321.

Hartıgan PJ, Griffin JFT, Nunn WR Some observations on Corynebacterium pyogenes infection of the bovine uterus. Thenogenology 1974, 1, 153167

Holt JG Bergey's Manual of Systematıc Bacteriology Vol. 2, Willıams and Wilkıns Co, Baltımore, 1986.

Imakawa K, Day L, Zalesky DD, Clutter A, Kittok RJ, Kinder $J E$ Effects of 17beta-estradiol and diets varying in energy on secretion of luteınizing hormone in beef heifers. J. Anım. Sc1. 1987, 64, 805815.

Kaneko K, Kawakamı S, Miyoshı M, Abukawa T, Yamanaka S, Mochizuki M, Yoshihara $S$ Effect of retained placenta on subsequent bacteriological and cytological intrauterine environment and reproduction in Holstein dairy cows. Thenogenology 1997, 48, 617-624.

Karg H, Scallenberger E. Factors influencing fertılity in the postpartum cow. Current Topics Vet. Med. Anım. Scı. Vol. 20 Martinus Nijhoff Publ., Boston 1982, MA. 63-72.

Kask K, Gustafsson H, Magnusson U, Bertilsson J, Kindahl $H$ Uterıne bacteriology, histology and granulocyte function of the postpartum cows in different milkıng frequencies. Submitted for publication 1998.

Kindahl H, Cort $N$, Fredriksson G, Edqvist L-E, Stabenfeldt $G$ Some aspects of the possible roles of diseases in altering reproductive performance. Proceedings of an International Symposium on the Use of Nuclear Techniques in Studies of Animal Production and Health in Different Environments jointly organized by the International Atomic Energy Agency and FAO of the United Nations, Vienna, 17-21 March, 1986, pp. 263273.

Kindahl H, Fredriksson G, MadeJ A, Edqvist L-E. Role of prostaglandins in uterine involution. 10th International Congress on Animal Reproduction and AI, Urbana-Champaign Illınors, June 10-14, 1984, Vol IV, CI-9-XI-16

Laitinen $J$ Oestrus confirmation, pregnancy diagnosis and postpartum ovarian follow-up of the Finnish dairy cows by milk progesterone assay. Thesis 1983, University of Kuopio, Finland.

Lamming GE, Peters AR, Rlley GM, Fisher MW Endocrine regulation of postpartum functions. Current Topics Vet Med Anim. Sci. 1982, 20, Martınus Nijhoff Publ., Boston, MA. 148-160.

Markusfeld $O$. Parturition disease complex of the high yielding dairy cow Acta vet. scand. Suppl. 1993, 89, 9-15.

Messier S, Higgins R, Couture Y, Morın M Comparison of swabbing and biopsy for studying the flora of the bovine uterus. Can. Vet. J. 1984, 25 , 283-288.

Olson J, Ball L, Mortımer RG, Farın PW, Adeny WS, Huffman $M \cdot$ Aspects of bacteriology and endocrinology of cows with pyometra and retained foetal membranes Am. J. vet. Res. 1984, 45, 2251-2255.

Roberts DS The pathogenic synergy of Fusiformis necrophorus and Corynebacterium pyogenes II. The response of $F$ necrophorus to a filterable product of $C$ pyogenes Br. J. Exp. Pathol. 1967, 48, 674-679.

Ruder CA, Sasser RG, Willams RJ, Ely JK, Bull RC, Butler $J E$. Uterine infection in the postpartum cow. effect of dietary crude protein restriction. Thenogenology 1981a, 15, 561-572.

Ruder CA, Sasser RG, Williams RJ, Ely JK, Bull RC, Butler JE Uterine infections in the postpartum cow: possible synergistic effect of Fusobacterium necrophorum and Corynebacterium pyogenes Theriogenology 1981b, 15, 573-579.

Skjerven $O$ Endometral biopsy studies in reproduc- 
tively normal cattle (Clinical, histochemical and histological observations during the oestrus cycle). Acta endocrinologica 1956, Supplementum 26 (PhD thesis)

\section{Sammanfattning \\ Bakterıologisk och histologisk undersokning av liv- modern hos nykalvade kor 1 två estländska mjölkkor besattningar}

Livmoderınfektıoner, endometriehıstologi och äggstocksaktıvitet studerades hos mjölkkor 12 estländska besättnıngar av olıka storlek och med olıka produktıons- och skotselnıvåer. T1o kor (besättnıng $\mathrm{A}$ ) och 5 kor (besảttnıng B) studerades 1 forsoket. Alla kor 1 studien hade en normal kalvning och var inte foremål for någon behandlıng. Endometriebiopsier for bakteriell och histologisk undersökning togs ut en gång per vecka med borjan andra veckan efter kalv- nıng och 7 veckor framåt. Mjolkprov för progesteronanalys togs 2 gånger per vecka under försoksper1oden. I båda besattningarna bestod bakteriefloran främst av fakultatıvt anaeroba bakterier (Streptococcus spp, E coll, Staphylococcus spp, Proteus vulgarts) Bland obligat anaerobık bakterier återfanns bara Bacteroides spp. I besättnıng $\mathrm{A}$ återfanns fortfarande bakterier 1 livmodern hos $10 \%$ av korna efter 7 veckors provtagnıng medan korna 1 besattnıng B var fria från bakterier efter 6 veckor Hos korna 1 besattning A noterades inflammatorıska celler 1 endometriet 1 hogre grad och senare 1gångsättnıng av àggstocksaktıviteten jamfort med korna 1 besattnıng B. Bara $60 \%$ av korna 1 besattning A hade haft sin forsta ovulatıon 7 veckor efter kalvning medan alla kor ovulerat 1 besattnıng B Studien visar att det förelıger skıllnader mellan besattnıngar avseende elımınation av livmoderınfektıoner efter kalvning men att kor med normal kalvnıng, blır fria från bakterıeınfektıoner utan någon behandlıng

(Recelved Aprll 17, 1998, accepted June 14, 1998)

Reprints may be obtained from. K. Kask, Department of Obstetrics and Gynaecology, Faculty of Veterınary Medıcıne, Estonıan Agrıcultural Unıversity, Tartu, Estonia. E-maıl kask@ph eau.ee, tel· +372 7466 201, fax $+3727422259$ 